Research paper

\title{
Impairment of microvascular angiogenesis is associated with delay in prostatic development in rat offspring of maternal protein malnutrition
}

\author{
Ketlin T. Colombelli, Sérgio A.A. Santos, Ana C.L. Camargo, Flávia B. Constantino, Caroline N. Barquilha, \\ Jaqueline C. Rinaldi, Sérgio L. Felisbino, Luis A. Justulin*
}

Department of Morphology, Institute of Biosciences, Sao Paulo State University, Botucatu, SP, Brazil

\section{A R T I C L E I N F O}

\section{Article history:}

Received 1 October 2016

Revised 13 December 2016

Accepted 28 December 2016

Available online 29 December 2016

\section{Keywords:}

Maternal protein malnutrition

Prostate morphogenesis

Angiogenesis

VEGF signaling

AQP1

Insulin/IGF

\begin{abstract}
A B S T R A C T
Experimental data demonstrated the negative impact of maternal protein malnutrition (MPM) on rat prostate development, but the mechanism behind the impairment of prostate growth has not been well understood. Male Sprague Dawley rats, borned to dams fed a normal protein diet (CTR group, 17\% protein diet), were compared with those borned from dams fed a low protein diet (6\% protein diet) during gestation (GLP group) or gestation and lactation (GLLP). The ventral prostate lobes (VP) were removed at post-natal day (PND) 10 and 21, and analyzed via different methods. The main findings were low birth weight, a reduction in ano-genital distance (AGD, a testosterone-dependent parameter), and an impairment of prostate development. A delay in prostate morphogenesis was associated with a reduced testosterone levels and angiogenic process through downregulation of aquaporin-1 (AQP-1), insulin/IGF-1 axis and VEGF signaling pathway. Depletion of the microvascular network, which occurs in parallel to the impairment of proliferation and differentiation of the epithelial cells, affects the bidirectional flux between blood vessels impacting prostatic development. In conclusion, our data support the hypothesis that a reduction in microvascular angiogenesis, especially in the subepithelial compartment, is associated to the impairment of prostate morphogenesis in the offspring of MPM dams.
\end{abstract}

(C) 2016 Elsevier Inc. All rights reserved.

\section{Introduction}

Malnutrition is a global problem, affecting mainly developing countries. Among the population, pregnant women and newborns are the most affected by malnutrition, leading to increased risks of morbidity and mortality for newborn infants (Gao et al., 2012). The idea that maternal exposure to adverse conditions impacts offspring health has been defined as a developmental origin of adult disease, also called the "Barker hypothesis" (Barker et al., 1989). It states that poor conditions during intrauterine life can result in permanent changes in physiology and metabolism. Due to obviously ethical considerations, there are few data about the effects of fetal programming on human health. Thus, the use of animal models is an important research tool in an attempt to elucidate the relationship between intrauterine malnutrition and diseases in adult life. In this sense, one of the most studied models is dams fed a low protein diet (Cezar de Oliveira et al., 2016; Ozanne, 2001;

\footnotetext{
* Corresponding author at: São Paulo State University (UNESP), Institute of Biosciences of Botucatu, SP 18618-689, Brazil.

E-mail address: justulin@ibb.unesp.br (L.A. Justulin).
}

Ozanne et al., 1999; Pinho et al., 2014; Rinaldi et al., 2013; Sene et al., 2013; Vega et al., 2016).

Although the effects of maternal protein malnutrition (MPM) have been first described with regard to the cardiorespiratory system in the last decade, experimental models have demonstrated that MPM also affects offspring reproductive parameters, such as decreased reproductive capacity in female and male rats (Guzmán et al., 2006, 2014) or impairment of sexual accessory gland development associated with reduction in circulating testosterone levels (Ramos et al., 2010; Rinaldi et al., 2013). Ramos et al. (2010) demonstrated a delay in dorsal prostate maturation in the offspring of rats fed a low protein diet during lactation. Other authors subsequently demonstrated impairment in prostate morphogenesis at post-natal day (PND) 1(Pinho et al., 2014) or maturation at PND30 and 120 in the offspring of dams fed a low protein diet during gestation (Rinaldi et al., 2013).

In addition to prostate androgenic dependence (Cunha et al. 1987), other factors such as insulin-like growth factors (IGFs), cytokines and adhesion molecules are also important to development, maturation and maintenance of glandular function (Timms et al., 1994; Prins and Putz, 2008). Another key factor is the nutritional support and oxygen supplied by blood vessels (Wong et al., 
2014). Vasculature is also responsible for delivery signaling molecules for prostate morphogenesis (Carmeliet, 2005). Development of the microvessel network and growth/elongation of the prostatic buds during glandular morphogenesis are closely related, both spatially and temporally (Wong et al., 2014). Among the regulatory genes involved in the angiogenesis process, the most studied is the vascular endothelial growth factor (VEGF) and its receptor VEGFR (Ferrara et al., 2003).

Although endothelial cells do not express androgen receptors (AR), studies have demonstrated the indirect involvement of androgens in the maintenance of the vascular structure and increased expression of angiogenic factors such as VEGF, VEGF-B, PLGF, and FGF-2, which act in a paracrine fashion, inducing endothelial proliferation (Prins et al., 1991). Considering the importance of nutritional and oxygen supplied by blood vessels for prostate morphogenesis, maturation and maintenance, we assessed whether maternal protein malnutrition impacts the process of angiogenesis in the ventral prostate of rat offspring. We demonstrated that, in parallel to the impairment of proliferation and differentiation of the epithelial cells, there is an intense reduction in prostate microvascular angiogenesis in offspring from MPM, especially in the subepithelial compartment, collaborating for the delay of ventral prostate morphogenesis.

\section{Material and methods}

\subsection{Animals and experimental design}

In our experiment, we used an established low protein diet (Pinho et al., 2014; Rinaldi et al., 2013; Sene et al., 2013), provided by PragSoluções (PragSoluções, SP, Brazil). All procedures described in this study were approved by the Biosciences Institute/UNESP Ethics Committee for Animal Experimentation (Protocol number 670). Adult female (90 days of age, $n=30$ ) and male (90 days of age, $\mathrm{n}=10$ ) Sprague Dawley rats were obtained from the Central Stock breeder at the State University of Campinas (Campinas, SP, Brazil). The animals were maintained under controlled temperature conditions (22 to $25^{\circ} \mathrm{C}$ ), relative humidity (55\%), and a $12 \mathrm{~h}$ photoperiod, with free access to water and chow.

Virgin female rats were mated overnight with established male breeders and after confirmation of mating; pregnant rats were housed individually in standard rat cages. They were fed an isocaloric and normosodic normal diet (17\% protein) or low protein diet (6\% protein) during gestation or during gestation and lactation (Table 1). To maximizing lactation performance, litters were reduced to eight pups at PND1: four males and four females (Fischbeck and Rasmussen, 1987; Rinaldi et al., 2013). Thus, the dams were divided into three experimental groups: Control (CTR), fed normal protein diet; Gestational low protein (GLP), fed low protein diet during gestation; and Gestational and lactational low protein (GLLP), fed low protein diet during gestation and lactation.

Maternal body weight was determined at the beginning of gestation (GD1) and at the end of the gestational period (GD21). The difference between body weight at GD1 and GD21 was used to demonstrate maternal bodyweight variation. Food intake of the dams and pups was measured throughout the experimental period. To calculate the relative food intake, the value of ingested food was divided by the bodyweight of the rats. The ano-genital distance (AGD) of male offspring was determined using a digital caliper (Digimess ${ }^{\circledR}$, Brazil) on PND1, 10 and 21. On PND 10 and 21, male rats from the CTR, GLP and GLLP groups ( $n=15 /$ group) were weighed and then euthanized using sodium pentobarbital anesthesia $(30 \mathrm{mg} / \mathrm{kg}$, i.p.) followed by decapitation. Blood samples were collected from ruptured cervical vessels. At PND10 and PND21,
Table 1

Composition of the control and low protein diets.

\begin{tabular}{|c|c|c|}
\hline Ingredientes (g/kg) & $\begin{array}{l}\text { Control diet } 17 \% \text { of } \\
\text { protein }\end{array}$ & $\begin{array}{l}\text { Low protein diet } 6 \% \text { of } \\
\text { protein }^{\#}\end{array}$ \\
\hline Cornstarch & 397 & 480 \\
\hline Caseín (84\%) & 202 & 71.5 \\
\hline Dextrin (90-94\%) & 130.5 & 159 \\
\hline Sucrose & 100 & 121 \\
\hline Soybean oil & 70 & 70 \\
\hline Fiber & 50 & 50 \\
\hline Mineral mix (AIN 93\%) & 35 & $35^{\dagger}$ \\
\hline Vitamin mix (AIN 93)* & 10 & 10 \\
\hline L-Cystine & 3 & 1 \\
\hline Choline bitartrate & 2.5 & 2.5 \\
\hline Total energy ( $\mathrm{kcal} \mathrm{g}^{-1}$ ) & 3.76 & 3.76 \\
\hline
\end{tabular}

\# The low protein diet was prepared by PragSoluções (PragSoluções, SP, Brazil). Diets were supplemented with L-Cystine as sulfur amino acid.

Vitamin and mineral mixtures were formulated to meet the American Institute of Nutrition AIN-93G recommendation for rodent diets (Reeves et al., 1993).

$\dagger$ Potassium phosphate, monobasic, was added to the salt mix of this diet to maintain phosphorus at the levels found in the control casein diet ( $3 \mathrm{~g} / \mathrm{kg}$ of diet) and the calcium:phosphorus ratio has been kept at 1.3 in both diets.

the VP lobes were removed, weighed and processed as described below. Such as prostate development in rodents starts at the end of the gestational period and continues after birth, the ingestion of a low protein diet during pregnancy and lactation affects the period of intense prostate development (Prins and Putz, 2008).

\subsection{Hormone assay}

For hormones measurement, blood samples ( $n=6 /$ group) from each animal were collected at the time of euthanasia. Serum was obtained after centrifugation ( $2400 \mathrm{~g}$ for $20 \mathrm{~min}$ ) and stored at $-20^{\circ} \mathrm{C}$. The concentrations of testosterone (Abcam, ab178663, CA, UK) at PND10, IGF-1 (R\&D, MG100, MA, USA) at PND10 and 21 and insulin (Millipore, EZRMI-13 k, MA, USA) at PND10 and 21 were determined by colorimetric method following the protocol of the manufacturers. The sensitivities of these assays were $0.06 \mathrm{pg} / \mathrm{mL}$ for testosterone, $0.1 \mathrm{ng} / \mathrm{mL}$ for insulin and $3.5 \mathrm{pg} / \mathrm{mL}$ for IGF-1. The intra-assay and inter-assay variations were $<10 \%$ for testosterone, 3.6 and $9.2 \%$ for the insulin and 5.6\% and $9.1 \%$ for IGF-1.

\subsection{Histological procedure}

Samples of VP from different experimental groups ( $n=5 /$ group) were fixed for $4 \mathrm{~h}$ in Methacarn (70\% methanol $+20 \%$ chloroform $+10 \%$ acetic acid). The samples were then dehydrated in ethanol, diaphanized in xylene and embedded in Paraplast (Sigma Co, Saint Louis, MO). $5 \mu \mathrm{m}$ sections were produced in rotative microtome, collected in silanized slides and stored until the time of use. The slides were stained with hematoxylin-eosin (HE) for morphological and stereological analyses. The sections were analyzed using a Leica DMLB 80 microscope connected to a Leica DC300FX camera. The digitalized images were analyzed using Leica Q-win software Version 3 for Windows.

The relative proportion of the VP components (epithelium, stroma and lumen) was determined by stereological analysis (Weibel et al., 1966). Random measurements were performed in 10 different fields (400X) and from five different individual prostatic lobe sections. The relative values were determined by counting the coincident points of the test grid and dividing them by the total number of points. The results were expressed as a percentage of each component and a proportion of the total area analyzed. 
2.4. Determination of smooth muscle $\alpha$-actin, ki67, AR and p63 indices at PND10

In order to determined whether MPM interferes with molecular markers of cellular differentiation, we conducted an immunohistochemical analysis of Ki67, AR, p63 and $\alpha$-actin in VP lobes at PND10 (5 pool of $2 \mathrm{VP} /$ group). Histological sections were subjected to antigen retrieval in a pressure cooker, with $10 \mathrm{mM}$ sodium citrate buffer $\mathrm{pH} 6.0$, for $30 \mathrm{~min}$. The slides were immersed in a solution containing 3\% hydrogen peroxide diluted in methanol to block endogen peroxidase for $10 \mathrm{~min}$. The sections were then washed in PBS, followed by treatment with $3 \%$ milk diluted in PBS to block unspecific protein-protein interactions. The slides were incubated overnight at $4{ }^{\circ} \mathrm{C}$ with the following primary antibodies: monoclonal anti-Ki-67 (diluted 1:150; ab16667-Abcam ${ }^{\circledR}$ ); polyclonal anti-androgen receptor (AR, 1:100; sc816-Santa Cruz ${ }^{\circledR}$ ); rabbit monoclonal anti-p63 (1:200; 5849 Bio SB), and mouse monoclonal $\alpha$-actin $\left(1: 100\right.$, sc32251-Santa $\left.\mathrm{Cruz}^{\circledR}\right)$, all diluted in 1\% BSA in PBS. The sections were washed 3 times in PBS for $5 \mathrm{~min}$ and incubated with the specific secondary antibodies conjugated with peroxidase, at room temperature. The reactions were developed using diaminobenzidine (DAB) and counterstained with hematoxylin. The Ki67, AR and p63 indices were expressed as percentages of positive cells from the total cells, counted in five histological sections of five VP lobes per group at 400X. Approximately 8000 cells were counted per experimental group. The results were expressed as mean $\pm S D$.

\subsection{Determination of microvascular density (MVD) and VEGF signaling molecules}

The MVD was determined in five histological sections of five VP lobes (400x) at PND10 and PND21 and immunostained for monoclonal anti-aquaporin 1 (AQP-1, 1:100, AB2219-Millipore ${ }^{\mathrm{TM}}$ ), a water channel protein strongly expressed in most microvascular endothelial cells (Verkman, 2002). The MVD was determined by stereological analysis (Weibel et al., 1966). Data are expressed as a percentage of microvessels per total area analyzed. The prostatic localization of VEGF and VEGFR, a central molecular signal involved in the angiogenic process, was also investigated. The slides of VP from all experimental groups at PND10 and PND21 were processed for immunohistochemistry (as described above) by using the primary antibody anti-VEGF (1:100; sc152-Santa $\left.\mathrm{Cruz}^{\circledR}\right)$ and VEGFR $\left(1: 100 ;\right.$ sc6251-Santa $\left.\mathrm{Cruz}^{\circledR}\right)$.

\subsection{Western blotting}

Frozen samples of VP lobes ( $n=5 /$ group) from all experimental groups at PND10 and PND21 were homogenized in extraction buffer (50 mM Tris- $\mathrm{HCl}, 0.25 \%$ Triton-X 100) and centrifuged, with the total protein determined as proposed by Bradford (Bradford, 1976). A total of $35 \mu \mathrm{g}$ was analyzed by electrophoresis using SDS-PAGE gel. Protein was trans-blotted onto the nitrocellulose membrane (Millipore, USA). Blots were blocked in 5\% non-fat milk diluted in PBS and incubated with the follow primary antibodies: anti-VEGF (1:1000; sc152-Santa Cruz $\left.{ }^{\circledR}\right)$; anti-VEGFR (1:1000; sc6251-Santa $\left.\mathrm{Cruz}^{\circledR}\right)$; and anti-aquaporin-1 (1:1000; AB 2219-Millipore $\left.{ }^{\mathrm{TM}}\right)$. The blots were washed in PBS and incubated with a specific secondary antibody for one hour. After washing with PBS again, the reactions were detected using an ECL kit (Amersham, USA). The substrate was removed from the membranes, and ECL signals were captured using a CCD camera (ImageQuant LAS $4000 \mathrm{mini}^{\circledR}$; GE Healthcare $^{\mathrm{TM}}$ ). The integrated optical densities (IODs) of the targeted protein bands were measured using Image J, which was downloaded from the NIH website (http://rsb.info.nih.gov.ij/). The expression levels were normalized to the $\beta$-actin (1:800;
sc1615-Santa $\mathrm{Cruz}^{\circledR}$ ) and the normalized results were expressed as the mean $\pm \mathrm{SD}$.

\subsection{Statistical analysis}

The statistical analyses were performed using GraphPad Prism ${ }^{\circledR}$ software (version 5.00, Graph Pad, Inc., San Diego, CA). The CTR and GLP dam groups were compared using the " $t$ " test with Welch correction. The other results were submitted to analysis of variance (ANOVA), followed by the "Tukey-Kramer" test. The results were expressed as mean \pm SD and differences were considered statistically significant when $p<0.05$.

\section{Results}

\subsection{Reproductive parameters of dams throughout pregnancy and pups at PNDO}

There is no difference between the bodyweight of the dams at the beginning of the experiment (GD1). At the end of the gestational period (GD21), both maternal bodyweight and weight-gain were lower in the restricted group than the CTR. The absolute and relative food consumption did not differ between the experimental groups (Table 2). These parameters were also evaluated in the dams at the beginning (PND1) and end of the lactation period (PND21). After birth (PND1), maternal bodyweight did not change among the experimental groups. However, there was a decrease in both restricted groups at PND21, with more evident reduction in the GLLP group compared to the CTR and GLP groups (Table 3). The maternal absolute food consumption was reduced in both restricted groups, with a significant difference detected between all groups (CTR > GLP > GLLP). The relative food consumption was lower in the GLLP group than the other age-matched groups (Table 3). No differences were observed in litter size, gestational length and male/female ratio between experimental groups (data not shown). At birth, the male pups borned of undernourished dams showed low birth weight, as well as reduced AGD compared to those in the CTR group (Table 4).

\subsection{Hormones and biometric parameters of male pups at PND10 and 21}

At PND10, the testosterone levels were significantly reduced in both restricted groups (GLP and GLLP) compared to CTR (Fig. 1A). The insulin quantification demonstrated no statistical differences among experimental groups at PND10. However, at PND21, the insulin levels decreased significantly in the restricted groups compared to the CTR (Fig. 1B). The IGF-1 levels were lower in the restricted groups at both ages, compared to the CTR group. Interestingly, at PND21, there is also a statistical difference IGF-1 levels between GLP and GLLP (Fig. 1C).

Table 2

Biometric parameters of pregnant rats

\begin{tabular}{lll}
\hline Dams Parameters & \multicolumn{2}{l}{ Experimental groups } \\
\cline { 2 - 3 } & CTR & GLP \\
\hline Body weight GD 1 $(\mathrm{g})$ & $232.53 \pm 25.28$ & $237.84 \pm 20.08$ \\
Body weight GD 21 $(\mathrm{g})$ & $368.04 \pm 16.49^{\mathrm{A}}$ & $342.97 \pm 17.42^{\mathrm{B}}$ \\
Body weight gain $(\mathrm{g})$ & $135.50 \pm 18.28^{\mathrm{A}}$ & $102.44 \pm 28.75^{\mathrm{B}}$ \\
Food consumption $(\mathrm{g})$ & $393.68 \pm 27.92$ & $429.00 \pm 35.54$ \\
Food consumption/BW & $1.24 \pm 0.40$ & $1.29 \pm 0.27$ \\
\hline
\end{tabular}

Data are expressed as mean \pm SD. Different letters demonstrate statistically difference between experimental groups with $\mathrm{p}<0.05$. BW: Body weight; GD: Gestational Day; CTR: Control group; GLP: Gestational Low Protein group. 
Table 3

Biometric parameters of dams at PND1 and PND21.

\begin{tabular}{llll}
\hline \multirow{2}{*}{$\begin{array}{l}\text { Parameters } \\
(\mathrm{n}=10 / \text { group })\end{array}$} & \multicolumn{3}{l}{ Experimental groups } \\
\cline { 2 - 4 } & CTR & GLP & GLLP \\
\hline Body weight PND 1 $(\mathrm{g})$ & $238.75 \pm 26.50$ & $235.78 \pm 20.68$ & $231.50 \pm 24.56$ \\
Body weight PND 21 $(\mathrm{g})$ & $236.76 \pm 17.93^{\mathrm{A}}$ & $224.03 \pm 18.83^{\mathrm{A}}$ & $193.73 \pm 13.00^{\mathrm{B}}$ \\
Body weight variation $(\mathrm{g})^{1.99 \pm 15.40^{\mathrm{A}}}$ & $11.74 \pm 12.37^{\mathrm{A}}$ & $36.14 \pm 14.85^{\mathrm{B}}$ \\
Food consumption $(\mathrm{g})$ & $677.80 \pm 84.05^{\mathrm{A}}$ & $550.26 \pm 93.91^{\mathrm{B}}$ & $372.54 \pm 85.35^{\mathrm{C}}$ \\
Food consumption/BW & $2.78 \pm 0.54^{\mathrm{A}}$ & $2.55 \pm 0.31^{\mathrm{A}}$ & $1.94 \pm 0.50^{\mathrm{B}}$ \\
\hline
\end{tabular}

Data are expressed as mean \pm SD. Different letters demonstrate statistically difference between experimental groups. BW: Body weight; CTR: Control group; GLP: Gestational Low Protein group; GLLP: Gestational and Lactational Low Protein group; PND: Post Natal Day.

Table 4

Male offspring biometric parameters at PND0.

\begin{tabular}{llll}
\hline Parameters $(\mathrm{n}=12)$ & \multicolumn{3}{l}{ Experimental groups } \\
\cline { 2 - 4 } & CTR & GLP & GLLP \\
\hline Body weight $(\mathrm{g})$ & $7.23 \pm 0.81^{\mathrm{A}}$ & $5.83 \pm 0.96^{\mathrm{B}}$ & $5.79 \pm 0.88^{\mathrm{B}}$ \\
AGD $(\mathrm{mm})$ & $2.84 \pm 0.42^{\mathrm{A}}$ & $2.62 \pm 0.28^{\mathrm{B}}$ & $2.51 \pm 0.33^{\mathrm{B}}$ \\
\hline
\end{tabular}

Data are expressed as mean \pm SD. Different superscript letters indicate significant differences among experimental ( $\mathrm{p}<0.05)$. AGD: Ano-Genital Distance; CTR: Control Group; GLP: Gestational Low Protein group; GLLP: Gestational and Lactational Low Protein group.

The absolute measurement of the pups bodyweight, AGD, and VP weights were significantly lower in both undernourished groups than the age-matched CTR groups at both ages (CTR $>$ GLP > GLLP). The reduction was more evident in the GLLP compared to the other groups (Fig. 2A and Table 4). Although we observed a tendency toward reduction in VP relative weight in both restricted groups compared to the age-matched CTR group, a statistical difference was only detected at PND21 (Table 5).

\subsection{Morphology and morphometric analyses of the ventral prostate at PND10 and PND21}

In both ages, the prostatic lobes from the restricted groups demonstrated an evident delay in glandular development and maturation compared to the age-matched CTR groups. At PND10, the VP lobes from the restricted groups showed an evident impairment of cellular polarization and acinar luminization (Fig. 2B). Although glandular growth progressed throughout the experimental period, the delay in glandular maturation persisted until PND21 in restricted groups. At this point, a decrease in luminal area was observed, associated with an increase in the stromal compartment (Fig. 2B). These results were confirmed by morphometricstereological analyses (Table 5).

\subsection{Determination of Ki67, AR, p63 and $\alpha$-actin expression}

The ki67 positive cells were detected in both the prostatic epithelial and stromal compartments. However, the number of ki67 positive nuclei was reduced in the restricted groups (Fig. 3), mainly in the GLLP group compared to the CTR group. The AR was also detected in the nuclei of both the epithelial and stromal cells. In the CTR group, the positive cells were detected mainly in the nuclei of luminal epithelial cells, However, in restricted groups, the number of positive epithelial cells was markedly reduced (Fig. 3). The immunostaining for p63 protein, a molecular marker of basalphenotype cells, demonstrated an increase of basal cell number in the restricted groups compared to the CTR group (Fig. 3). The intensity of $\alpha$-actin immunoreaction was visually reduced in the GLP and GLLP groups compared to the CTR group. This result suggests a delay in the process of mesenchymal cell differentiation into smooth muscle cells in the VP of the undernourished offspring (Fig. 3). The determination of the Ki67, AR and p63 indices confirmed the results observed in the immunohistochemistry reaction (Fig. 3).

\subsection{Determination of AQP-1, VEGF and VEGFR expression and microvascular density (MVD)}

The VP of undernourished groups presented a reduced expression of VEGF in at both ages (PND10 and PND21), with significant differences observed between the GLLP groups and the agematched groups (Fig. 4). The VEGF-R expression also significantly decreased in the restricted groups, between all experimental groups (GLLP < GLP < CTR) (Fig. 5). The immunostaining for AQP1 , used to visualize the VP microvasculature, demonstrated an intense reduction in blood supply, mainly in the subepithelial capillaries, in the restricted group compared to the CTR group at PND 10 (Fig. 6). This reduction persisted until PND21. The determination of MVD confirmed the results of the immunohistochemistry analysis (Table 5).

The Fig. 7 summarizes the main findings of our study. The MPM impairs ventral prostate microvascular angiogenesis. In parallel, we also observed a delay in epithelial cell proliferation and differentiation. In this sense, we hypothesize there is a reduction of the physiological bilateral flux of molecules involved in leading to a delay in prostate morphogenesis in the male undernourished offspring.

\section{Discussion}

The novelty of this study is to demonstrate the impairment of microvascular angiogenesis occurs in parallel to the retardation of cellular proliferation and differentiation, and it can be associated

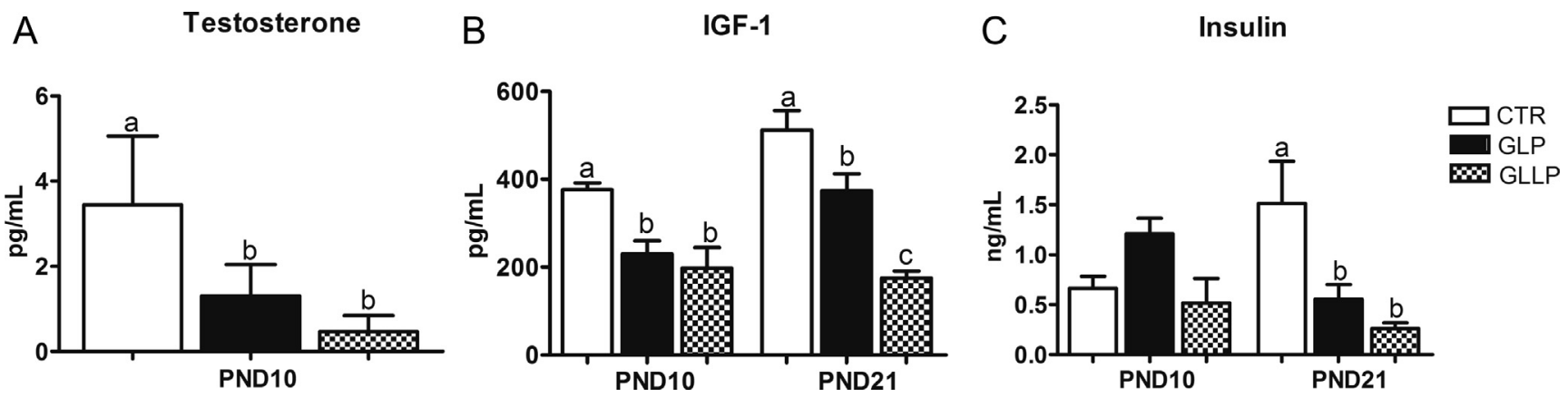

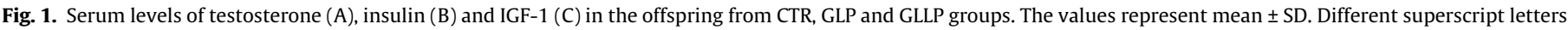
means statistically significantly among experimental groups with $\mathrm{P}<0.05$. 

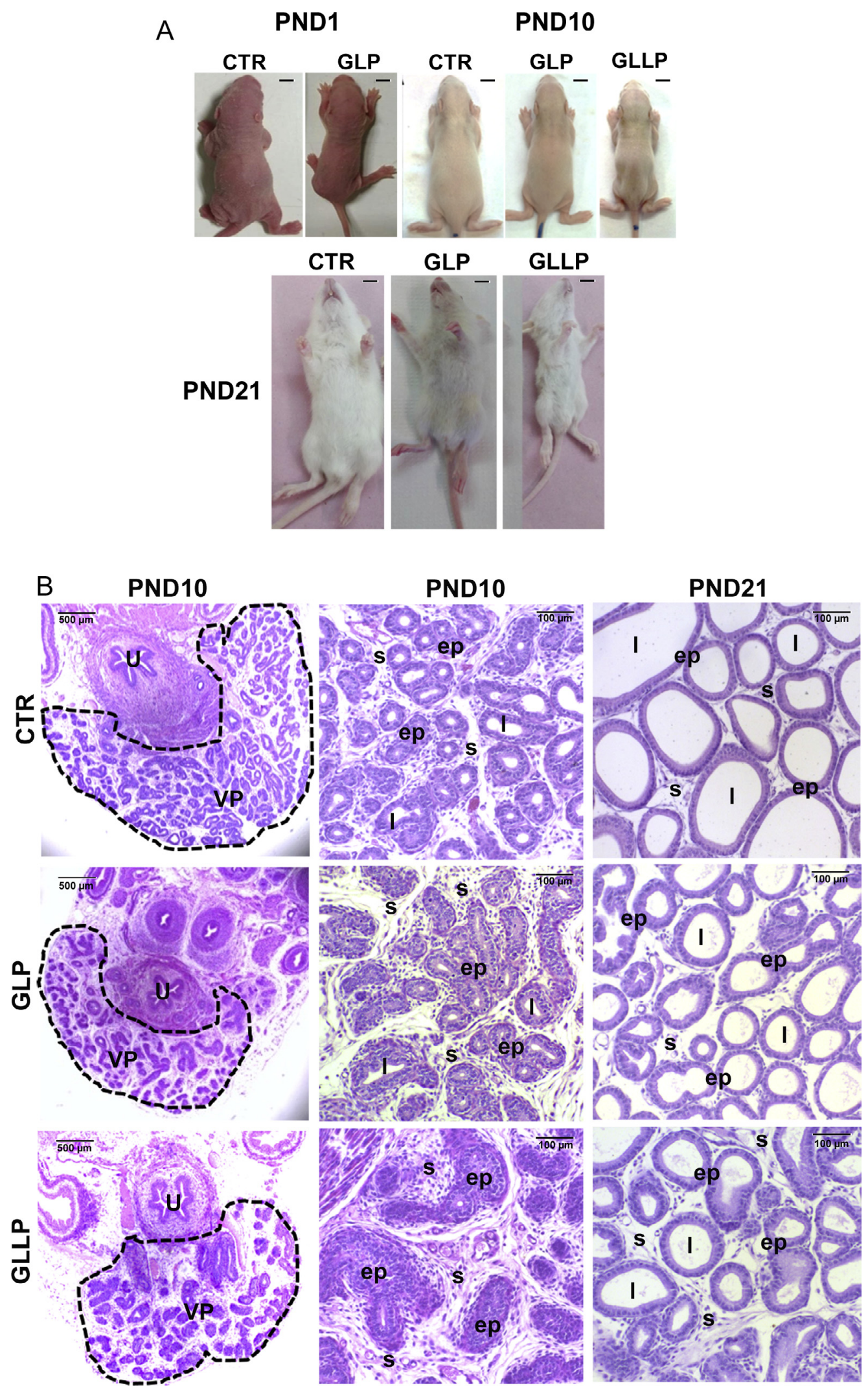

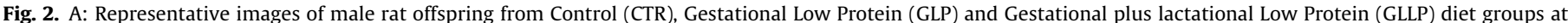

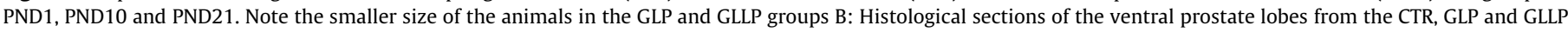

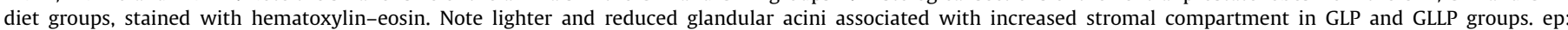
epithelium; s: stroma; l: lumen. In the Fig. $1 \mathrm{~A}$, scale bars represents $1 \mathrm{~cm}$. 
Table 5

Biometric and morphological-stereological parameters of rat VP from different experimental groups.

\begin{tabular}{|c|c|c|c|c|c|c|}
\hline \multirow[t]{2}{*}{ Parameters $(n=12)$} & \multicolumn{6}{|c|}{ Experimental Groups } \\
\hline & CTR (PND10) & GLP & GLLP & CTR (PND21) & GLP & GLLP \\
\hline \multicolumn{7}{|l|}{ Biometric data } \\
\hline Body weight (g) & $24.34 \pm 2.23^{\mathrm{A}}$ & $18.85 \pm 2.70^{\mathrm{B}}$ & $10.84 \pm 1.98^{\mathrm{C}}$ & $39.25 \pm 9.37^{A}$ & $27.72 \pm 6.82^{\mathrm{B}}$ & $20.03 \pm 3.87^{C}$ \\
\hline $\operatorname{AGD}(\mathrm{mm})$ & $6.84 \pm 0.64^{\mathrm{A}}$ & $6.37 \pm 0.73^{B}$ & $5.12 \pm 0.57^{\mathrm{C}}$ & $10.69 \pm 2.54^{\mathrm{A}}$ & $8.57 \pm 1.55^{\mathrm{B}}$ & $7.25 \pm 1.07^{\mathrm{B}}$ \\
\hline VP absolute weight (mg) & $4.13 \pm 1.65^{\mathrm{A}}$ & $2.60 \pm 0.83^{\mathrm{B}}$ & $1.68 \pm 0.69^{\mathrm{C}}$ & $32.02 \pm 7.95^{\mathrm{A}}$ & $26.51 \pm 5.60^{\mathrm{B}}$ & $14.40 \pm 3.87^{C}$ \\
\hline VP relative weight & $0.17 \pm 0.06$ & $0.13 \pm 0.03$ & $0.14 \pm 0.06$ & $1.16 \pm 0.29^{\mathrm{A}}$ & $0.96 \pm 0.18^{\mathrm{B}}$ & $0.79 \pm 0.15^{\mathrm{B}}$ \\
\hline \multicolumn{7}{|c|}{ Relative frequency of VP compartments } \\
\hline Epithelium & $52.53 \pm 6.61^{\mathrm{A}}$ & $47.94 \pm 8.57^{\mathrm{B}}$ & $46.17 \pm 8.67^{\mathrm{B}}$ & $35.71 \pm 7.45^{\mathrm{A}}$ & $45.45 \pm 9.89^{B}$ & $48.05 \pm 7.53^{\mathrm{B}}$ \\
\hline Lumen & $2.77 \pm 2.30^{\mathrm{A}}$ & $1.44 \pm 1.50^{\mathrm{B}}$ & $1.41 \pm 1.42^{\mathrm{B}}$ & $45.46 \pm 12.47^{\mathrm{A}}$ & $30.50 \pm 6.16^{\mathrm{B}}$ & $25.40 \pm 8.96^{\mathrm{B}}$ \\
\hline Stroma & $44.69 \pm 6.45^{\mathrm{A}}$ & $50.51 \pm 8.89^{\mathrm{B}}$ & $52.32 \pm 9.48^{\mathrm{B}}$ & $19.79 \pm 6.35^{\mathrm{A}}$ & $26.82 \pm 7.21^{\mathrm{B}}$ & $29.63 \pm 7.29^{\mathrm{B}}$ \\
\hline MVD & $14.76 \pm 2.88^{A}$ & $9.77 \pm 2.76^{\mathrm{B}}$ & $9.54 \pm 3.02^{\mathrm{B}}$ & $10.77 \pm 4.19$ & $8.70 \pm 2.23$ & $8.89 \pm 1.58$ \\
\hline MVD/Stroma ratio & $0.30 \pm 0.07^{\mathrm{A}}$ & $0.15 \pm 0.04^{\mathrm{B}}$ & $0.17 \pm 0.06^{\mathrm{B}}$ & $0.82 \pm 0.47^{\mathrm{A}}$ & $0.46 \pm 0.23^{\mathrm{B}}$ & $0.42 \pm 0.15^{\mathrm{B}}$ \\
\hline
\end{tabular}

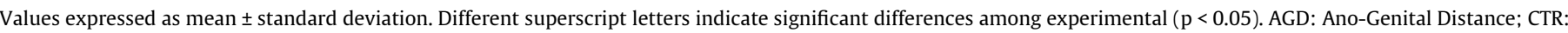

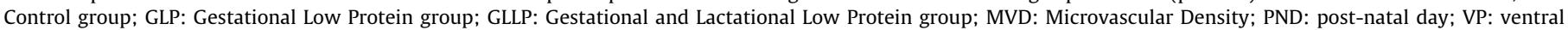
prostate.

to the delay of ventral prostate morphogenesis in the offspring of maternal protein restricted rats. The decrease in the prostate angiogenic process probably occurs through downregulation of AQP1, VEGF signaling and the reduction of the testosterone and insulin/IGF axis.

A large number of clinical and experimental studies have demonstrated the negative impact of maternal malnutrition on the health of offspring, from low birth weight to the development of metabolic syndrome, type 2 diabetes and cardiovascular diseases with aging. Overall, our results regarding to offspring birth weight, body weight gain and insulin or IGF-1 circulating levels corroborate to the literature data (Barker et al., 1989, 1993; Gosby et al., 2009; Langley-Evans and Sculley, 2006; Barker and Thornburg, 2013; Dearden and Ozanne, 2014; Tarry-Adkins and Ozanne, 2014; Hivert et al., 2015; Thornburg, 2015; Charles et al., 2016). Thus, we believe that our data reinforce the impact of maternal protein malnutrition on offspring development and growth.

With regard to reproductive parameters, it has been demonstrated that MPM delays sexual maturation and decreases reproductive capacity in adult female offspring (Guzmán et al., 2006). In male offspring, there was an observed reduction in ano-genital distance, testosterone levels (Ramos et al., 2010; Rinaldi et al., 2013; Pinho et al., 2014) and reproductive capacity (Rodríguez-G onzález et al., 2014). Although the negative effects of MPM on the reproductive capacity of offspring has already been described, the impact of maternal protein restriction on the pups prostates has only gained attention in the last five or six years. The first authors to highlight the result of maternal protein restriction on the prostate were Ramos et al. (2010), who demonstrated a reduction in the glandular compartment of the dorsal prostate lobe in the offspring of dams fed a low protein diet during lactation. Later, other authors demonstrated a delay in prostate morphogenesis at PND1 (Pinho et al., 2014) or maturation at PND30 and 120 in offspring from dams fed a low protein diet during gestation (Rinaldi et al., 2013). These results have been associated with a reduction in cellular proliferation and differentiation, influenced by decreased testosterone and DHT serum levels in the male offspring from restricted dams (Rinaldi et al., 2013; Pinho et al., 2014). In this study, we also demonstrated a reduction in AGD and cellular proliferation and differentiation, as well as highlighting the reduction of microvascular angiogenesis as a new event associated with the impairment of prostate morphogenesis and growth in restricted offspring.

Although prostate development and secretory function depend on androgen stimulation, a plethora of cytokines, adhesion molecules, growth factors, nutrients and oxygen (supplied by blood vessels) are also essential for maintenance of prostatic growth and function. Wong et al. (2014) suggested that there is a coordinated spatial and temporal distribution of the vascular network and tips of the prostatic ducts from an early stage of development in mice. In our study, we demonstrated the distribution of a great network of subepithelial capillaries in the CTR group, and a significant reduction of microvascular density, mainly at the subepithelial region, in offspring from restricted dams. This result was also confirmed by the calculation of the MVD/Stromal ratio, which demonstrated that even the stromal compartment showed an increase in the VP of restricted animals, in addition to the stromal vasculature being reduced. We associated these changes to the impairment of glandular morphogenesis in these animals. Our proposal is supported by other studies that demonstrated a reduced angiogenic process in pups born to low protein fed dams, including in the brain, duodenum (Bennis-Taleb et al., 1999), pancreas (Snoeck et al., 1990) and kidney medulla (Khorram et al., 2007).

In order to elucidate a possible pathway involved in the reduction of microvascular density in restricted pups, we investigated the VEGFA and VEGFR2 protein expression in the VP offspring. Both VEGFA and VEFR2 were downregulated in VP from restricted offspring, especially in the GLLP group. The VEGFA belongs to the Platelet-derived growth factor receptor (PDGF) supergene family, which also includes VEGFB, VEGFC, VEGFD, VEGFE, VEGFF and Placenta Growth Factor (PIGF) (Ferrara et al., 2003). Among these, VEGFA is found to be the proangiogenic factor that best induces endothelial cell proliferation, sprouting, migration and tube formation (Tammela et al., 2005). VEGFA signaling is mediated by specific receptors, VEGFR1 and 2. VEGFR2 regulates the endothelial mitogenic activity of VEGFA, whereas VEGFR1 acts as a negative regulator of VEGFR2 (Cébe-Suarez et al., 2006). Moreover, studies in humans and mice indicate the essential role of IGF-1 in developmental angiogenesis (Smith et al., 1999), stimulating endothelial differentiation, migration and formation of capillary-like structure (Viana et al., 2015). Thus, the downregulation of VEGFA signaling associated with reduction of circulating IGF-1 in protein restricted offspring can be related to the decrease in microvascular density and a delay in VP development. Similar results were observed by Liu et al. (2014), who described how downregulation of VEGF signaling plays a central role in the impairment of lung development in the offspring of maternal protein restricted dams.

Although the importance of VEGF to the angiogenic process recognized, it has been demonstrated that VEGF also exerts a central role in mammary gland differentiation and milk production, since inactivation of VEGF impairs mammary gland alveologenesis and epithelial differentiation during lactation, and administration of recombinant VEGF reversed this effect (Rossiter et al., 2007). In this 


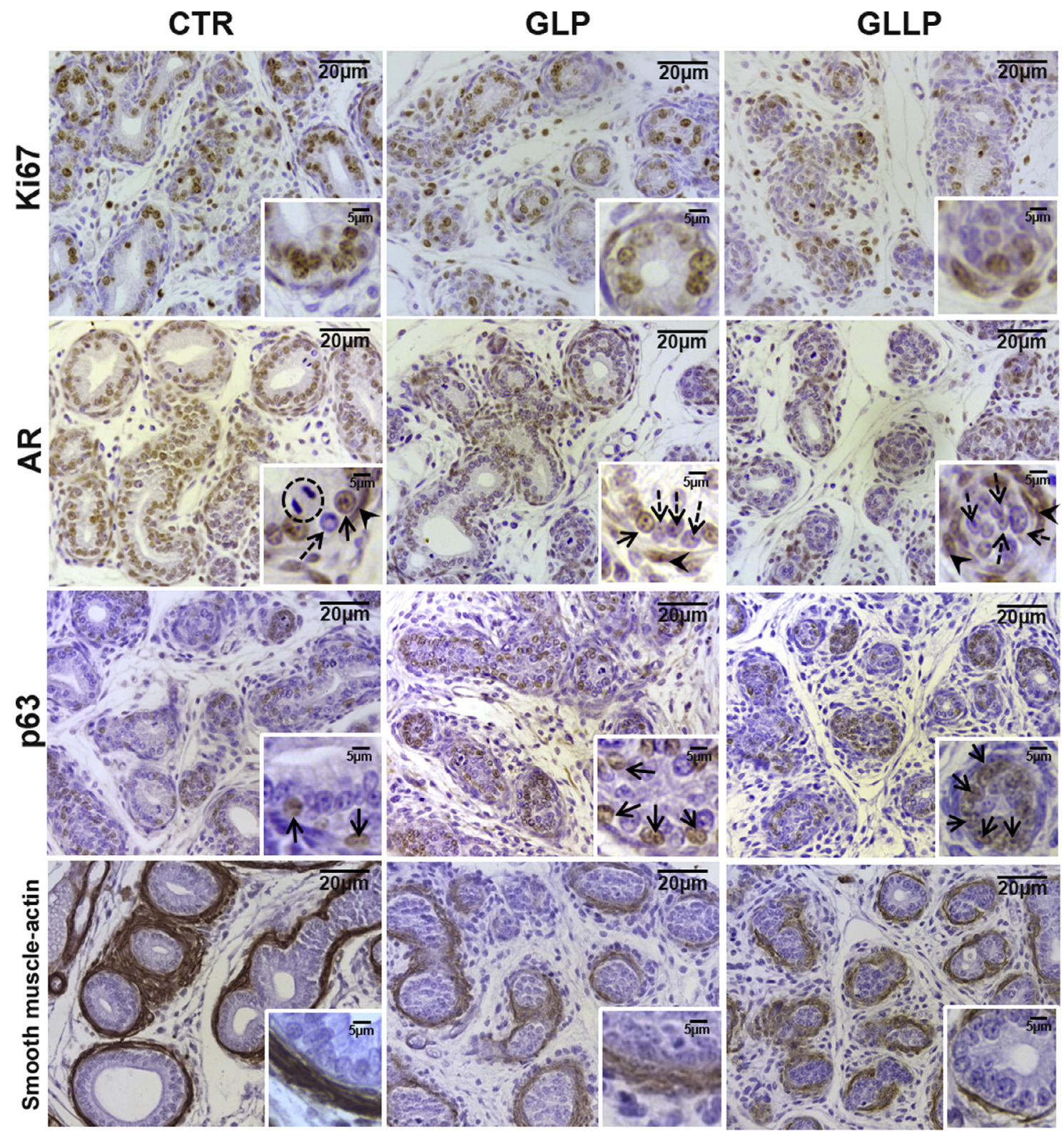

Ki67 positive cells

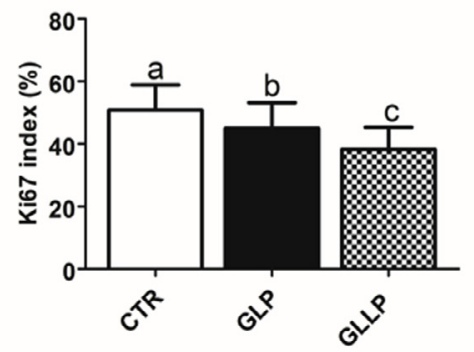

AR positive epithelial cells

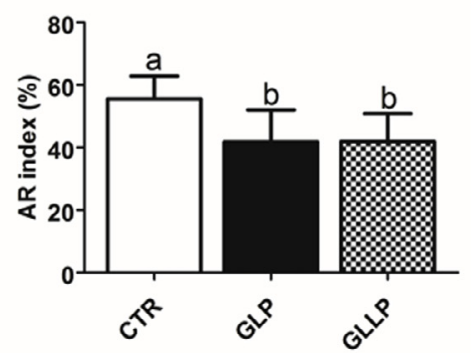

p63 positive cells

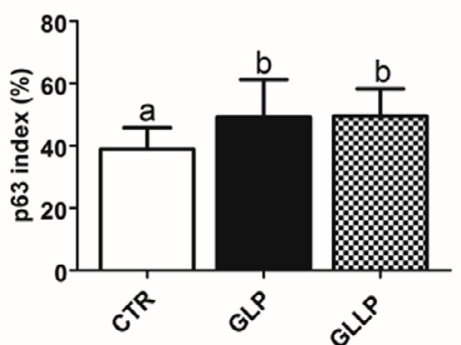

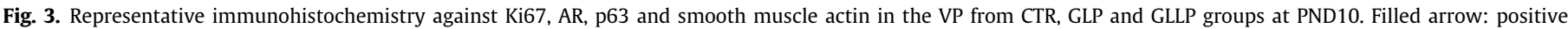

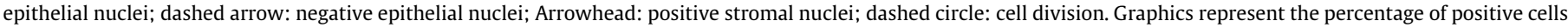
for each marker in the VP from all experimental groups $(n=5$ /group). Data were expressed as mean \pm SD. Different letters means statically differences with $p<0.05$.

study, we also observed impairment in cellular differentiation and proliferation in restricted groups, as demonstrated by an increase in p63 positive basal cells, a reduction in AR positive luminal cells and the immunostaining of stromal $\alpha$-actin. A reduction of cellular 


\section{PND 10}
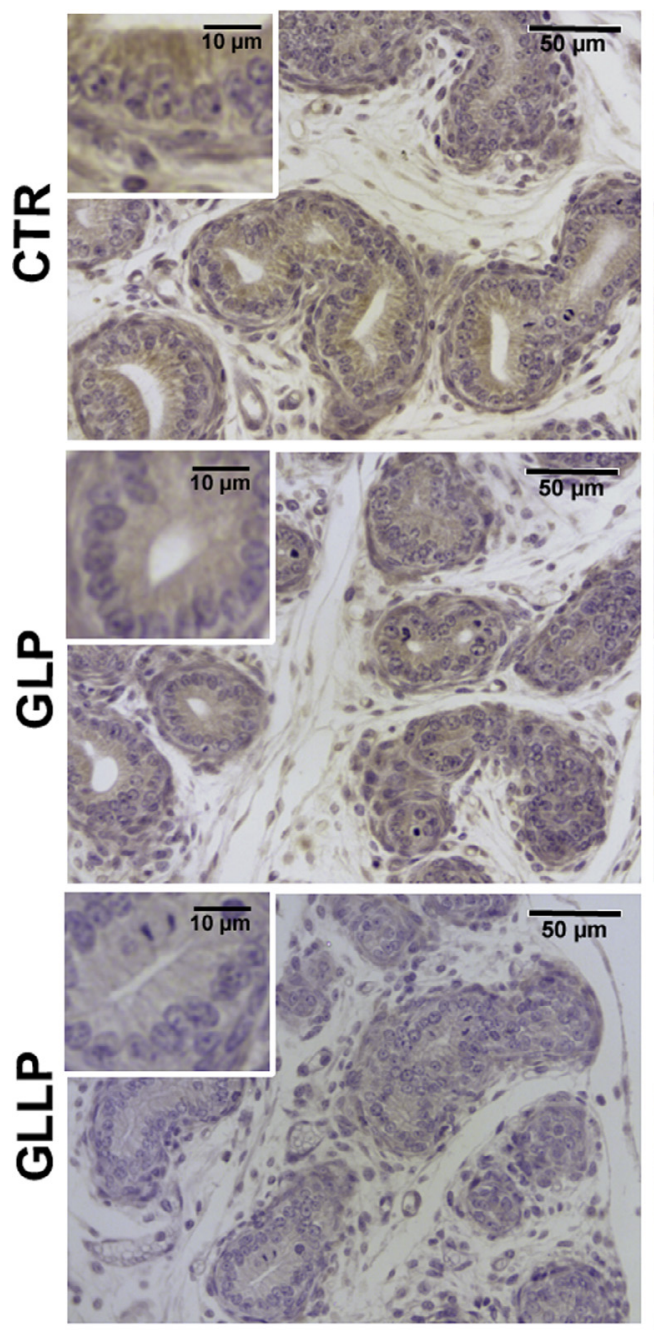

VEGF-A PND10
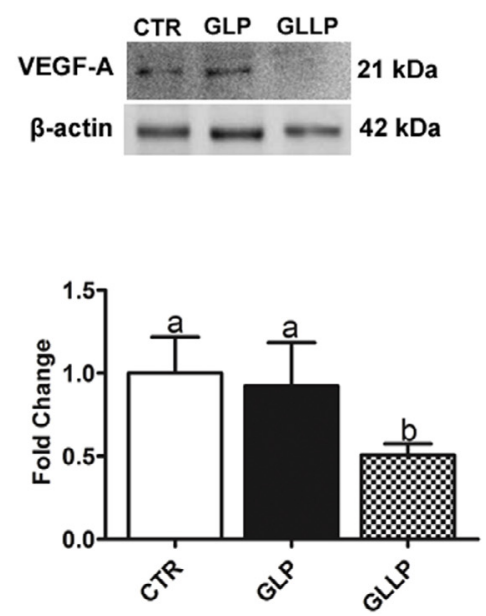

PND 21
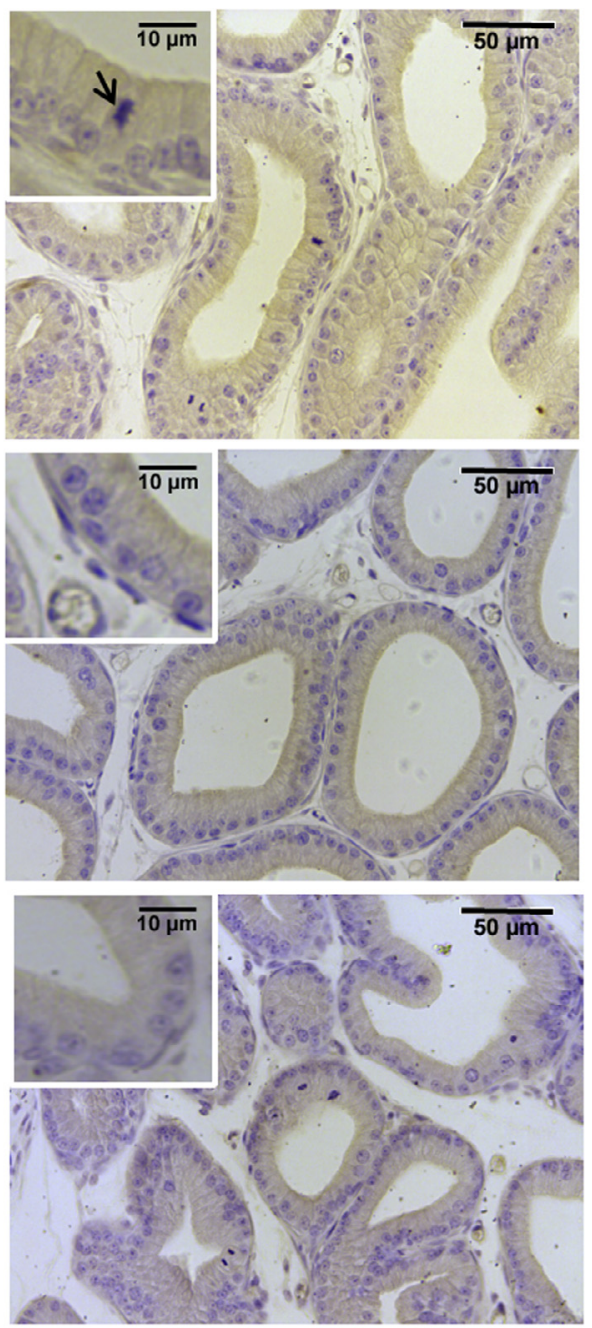

\section{VEGF-A PND21}

CTR GLP GLLP
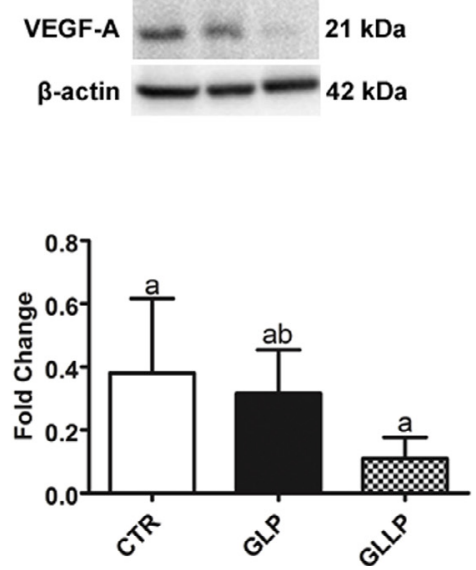

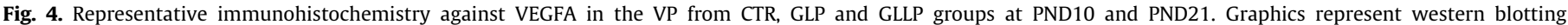

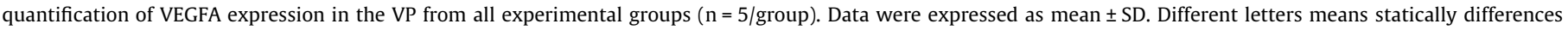
with $\mathrm{p}<0.05$.

differentiation markers was also demonstrated by Pinho et al. (2014) in restricted offspring at PND1. Together, our results demonstrated that a reduction in microvascular density, mainly in the subepithelial region, can lead to an ineffective diffusion of 


\section{PND10}
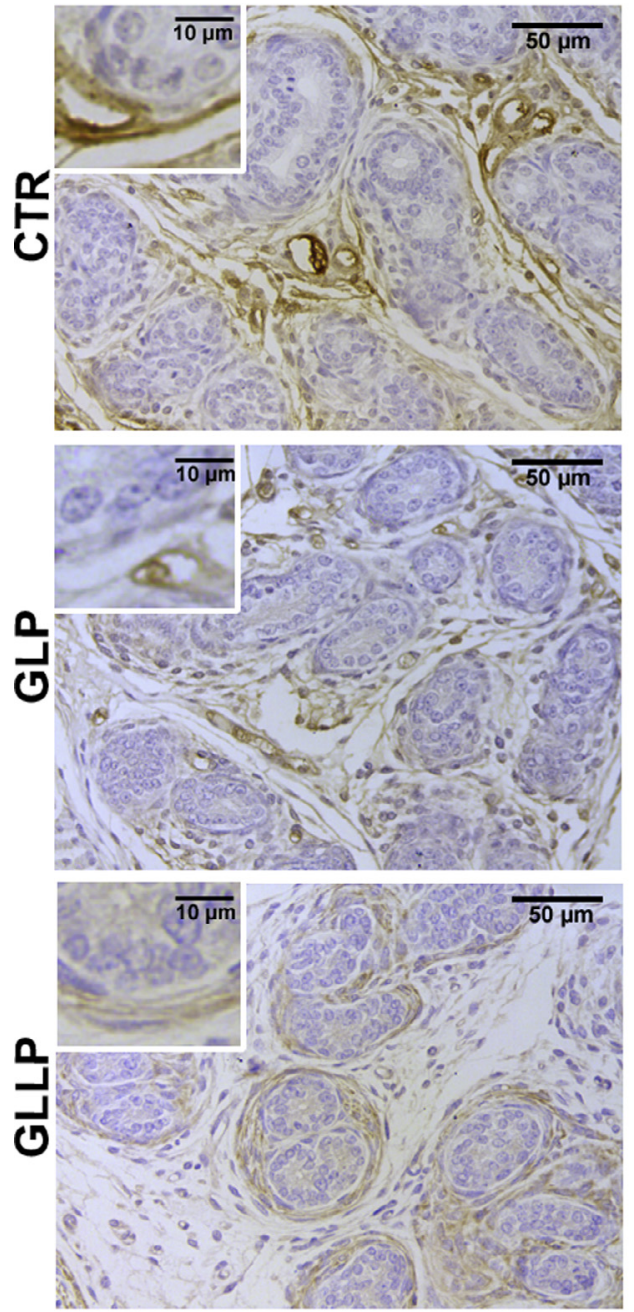

VEGFR PND10
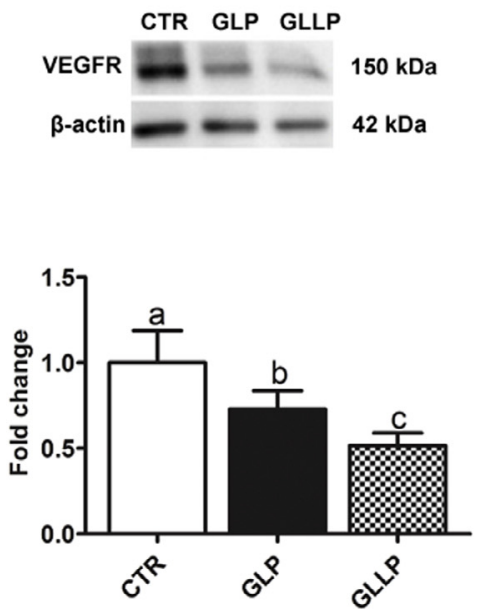

PND21
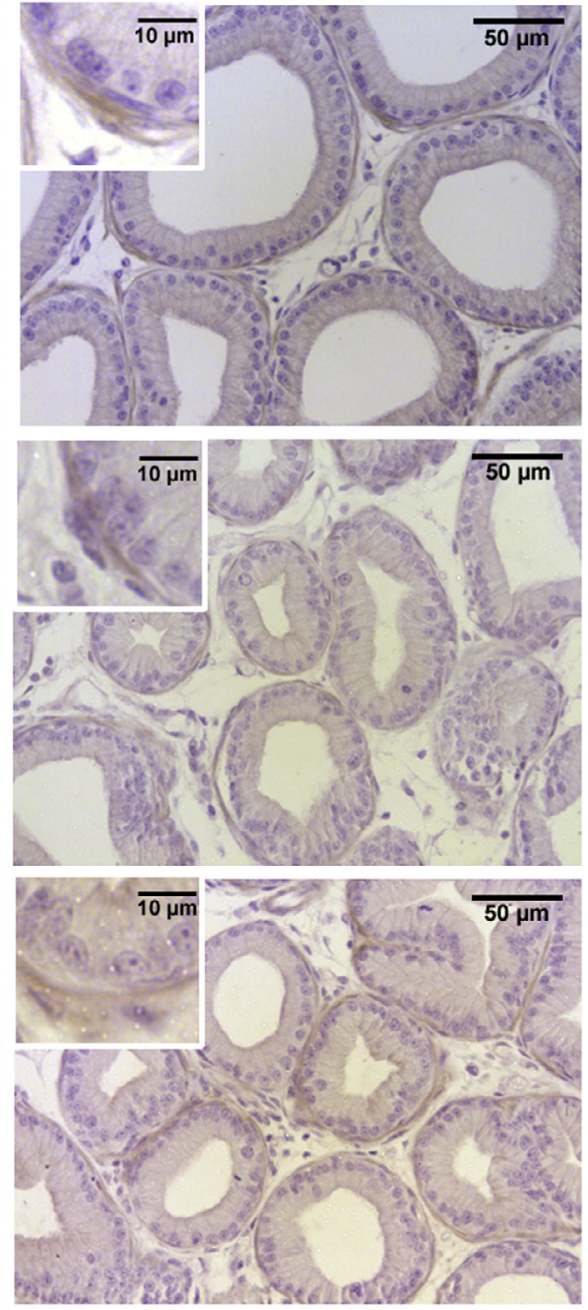

VEGFR PND21

CTR GLP GLLP

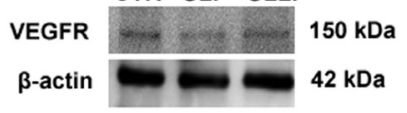

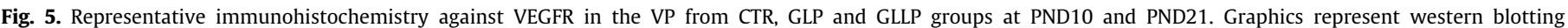

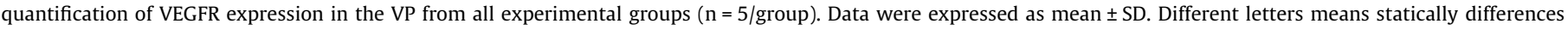
with $\mathrm{p}<0.05$.

hormones, growth factors, and oxygen, resulting in decreased stimulatory molecules related to cellular differentiation and glandular morphogenesis. In addition to VEGF signaling, AQP1's central role as the inductor of angiogenesis has been demonstrated in both 


\section{PND10}
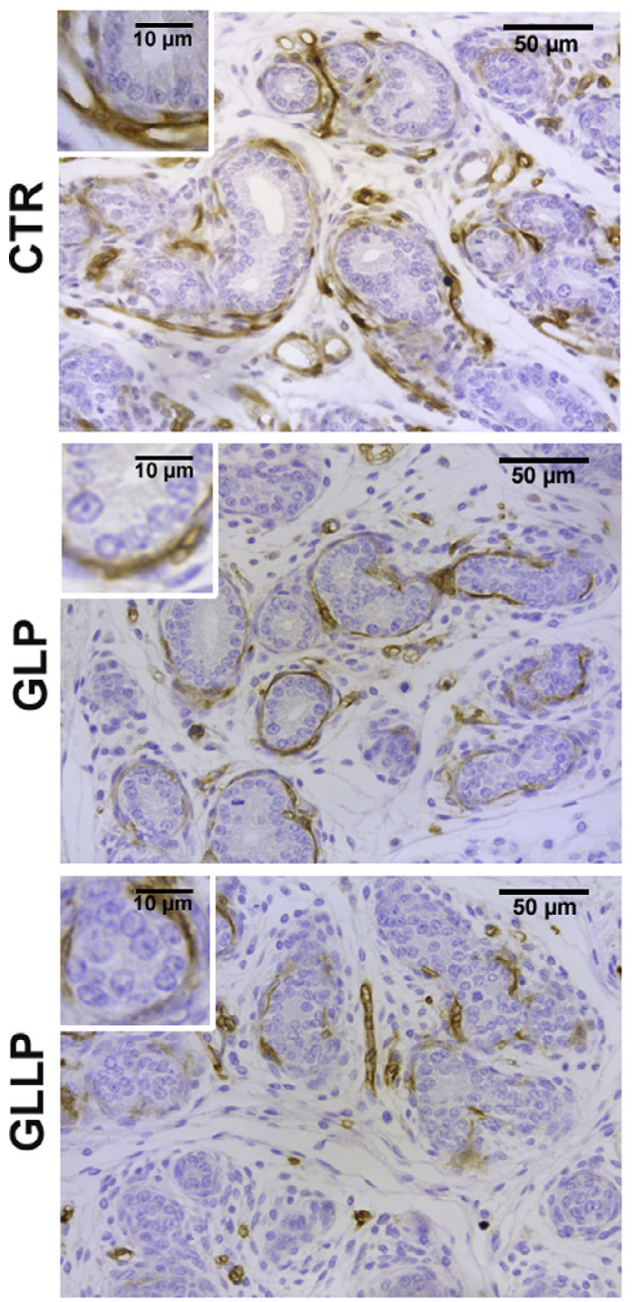

AQP-1 PND10
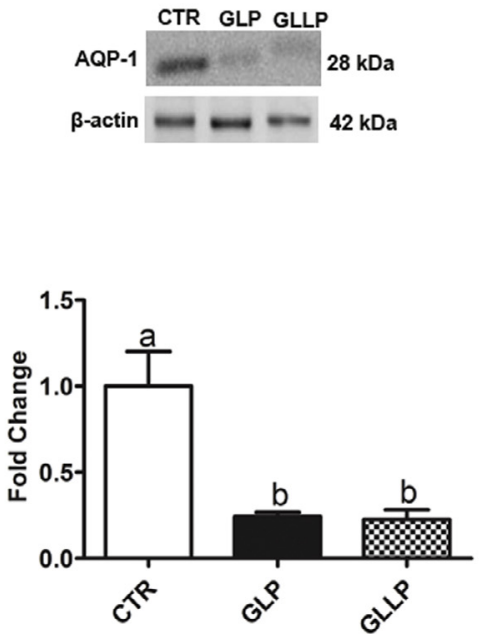

\section{PND21}
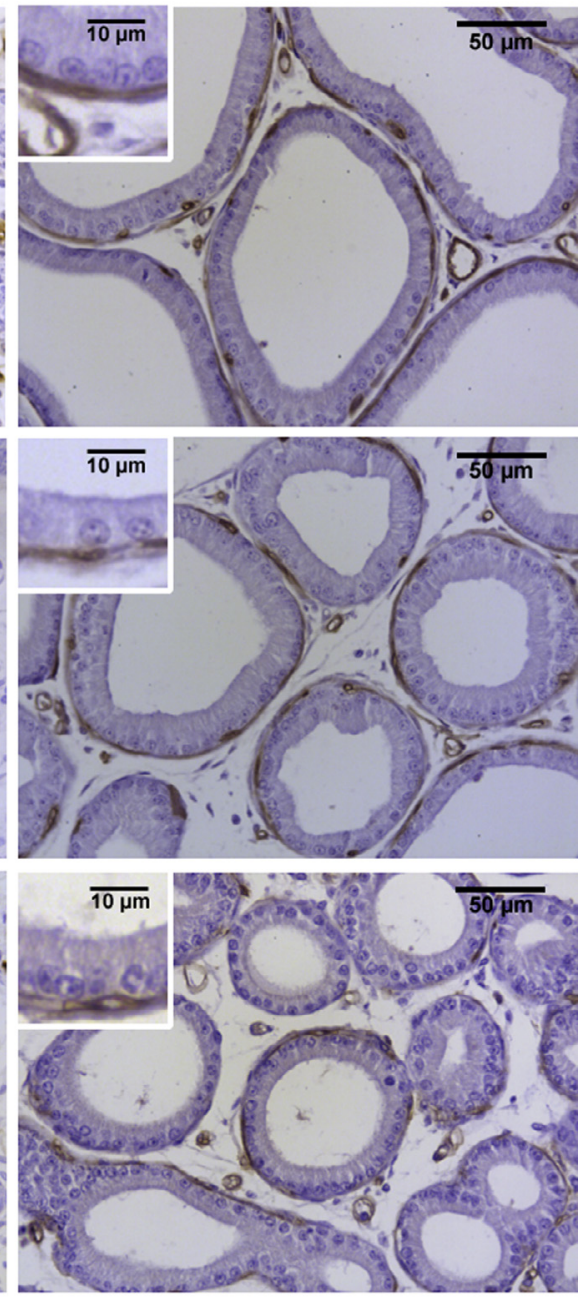

AQP-1 PND21

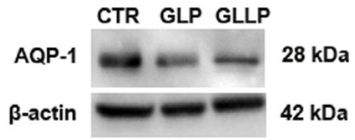

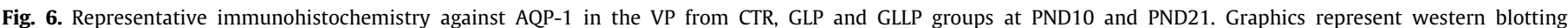

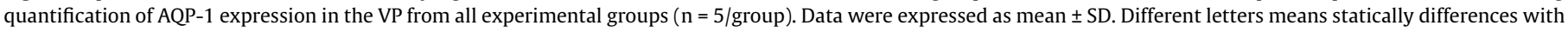
$\mathrm{p}<0.05$.

the normal and pathologic condition (Saadoun et al., 2005). AQP1 belongs to a family of proteins expressed on the plasma membrane of cells involved in fluid transport (Sha et al., 2011). AQP1 is expressed in various organs and cells (microvascular endothelial 


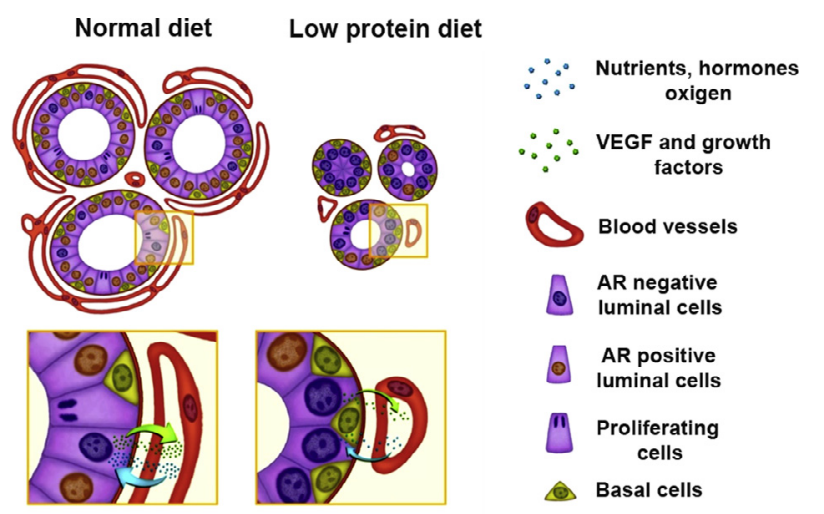

Fig. 7. Schematic view of the ventral prostate from CTR, GLP and GGLP groups demonstrating the main findings of our study. In the restricted groups, the impairment of glandular compartment occurs in parallel to the intense reduction in the blood vessel supply and in the bidirectional exchange of nutrients, hormones and growth factors between vascular network and prostatic tissues. At the cellular levels, the maternal protein restriction was associated with the increase in the p63positive basal cells and the reduction in the AR-positive epithelial cells, as well as epithelial cellular proliferation. Collectively, these changes lead to an intense delay in the ventral prostate development in offspring from restricted dams.

cells, kidney, central nervous system, eye, lacrimal and salivary glands, respiratory apparatus, gastrointestinal tract, hepatobiliary compartments, female and male reproductive system). An increase in the expression of AQP1 has been associated with stimulation of endothelial cell proliferation, migration and angiogenesis (Clapp and De La Escalera, 2006). AQP1 is strongly expressed in most microvasculature endothelial cells (Au et al., 2008; Kim and Jung, 2011) and it can be used as a molecular marker for vascular microstructure. We believe that a decrease in AQP1 in restricted groups may be associated with a reduction in microvascular density through downregulation of endothelial cell proliferation and migration in the ventral prostate.

In summary, our results have shown a delay in proliferation/differentiation rates in parallel to the impairment of angiogenesis process in the prostate from MPM groups, especially in the subepithelial region. These events can be implicate with prostatic subdevelopment observed in offspring from restricted dams.

\section{Conclusion}

In conclusion, to our knowledge, this is the first study demonstrating that MPM impairs prostatic microvascular angiogenesis in male offspring. We propose that the reduction in subepithelial microvasculature is associated with a delay in cellular proliferation and differentiation, contributing to the impairment of prostate morphogenesis and growth in offspring from protein restricted dams.

\section{Acknowledgment}

This manuscript comprises part of the Mater's degree of KTC. We are very grateful to Suelen Franco, Bianca Martins and Luiz Marcos Frediani Portela for their technical assistance and César Claro Trevelin for the illustration. This study was supported by Fundação de Amparo à Pesquisa do Estado de São Paulo, grant no. 2013/24230-5, Coordination for the Improvement of Higher Education Personnel (CAPES) and UNESP.

\section{References}

Au, C.G., Butler, T.L., Egan, J.R., Cooper, S.T., Lo, H.P., Compton, A.G., North, K.N., Winlaw, D.S., 2008. Changes in skeletal muscle expression of AQP1 and AQP4 in dystrophinopathy and dysferlinopathy patients. Acta Neuropathol. 116, 235246. http://dx.doi.org/10.1007/s00401-008-0369-z.
Barker, D.J.P., Thornburg, K.L., 2013. The obstetric origins of health for a lifetime. Clin. Obstet. Gynecol. 56, 511-519. http://dx.doi.org/10.1097/ GRF.0b013e31829cb9ca.

Barker, D.J., Osmond, C., Golding, J., Kuh, D., Wadsworth, M.E., 1989. Growth in utero, blood pressure in childhood and adult life, and mortality from cardiovascular disease. BMJ 298, 564-567. http://dx.doi.org/10.1136/ bmj.298.6673.564.

Barker, D.J., Gluckman, P.D., Godfrey, K.M., Harding, J.E., Owens, J.A., Robinson, J.S. 1993. Fetal nutrition and cardiovascular disease in adult life. Lancet. 341, 938941.

Bennis-Taleb, N., Remacle, C., Hoet, J.J., Reusens, B., 1999. A low-protein isocaloric diet during gestation affects brain development and alters permanently cerebral cortex blood vessels in rat offspring. J. Nutr. 129, 1613-1619.

Bradford, M.M., 1976. A rapid and sensitive method for the quantitation of microgram quantities of protein using the principle of protein dye binding. Anal. Biochem. 72, 248-254. http://dx.doi.org/10.1016/0003-2697(76)90527-3.

Carmeliet, P., 2005. Angiogenesis in life, disease and medicine. Nature 438, 932936. http://dx.doi.org/10.1038/nature04478.

Cébe-Suarez, S., Zehnder-Fjällman, A., Ballmer-Hofer, K., 2006. The role of VEGF receptors in angiogenesis; complex partnerships. Cell. Mol. Life Sci. http://dx. doi.org/10.1007/s00018-005-5426-3.

Cezar de Oliveira, J., Gomes, R.M., Miranda, R.A., Barella, L.F., Malta, A., Martins, I.P., da Silva Franco, C.C., Pavanello, A., Torrezan, R., Marçal Natali, M.R., Lisboa, P.C., de Freitas Mathias, P.C., Gasde de Moura, E., 2016. Protein-restriction during the last third of pregnancy malprograms the neuroendocrine axes to induce metabolic syndrome in adult male rat offspring. Endocrinology. http://dx.doi. org/10.1210/en.2015-1883. en20151883.

Charles, M.-A., Delpierre, C., Bréant, B., 2016. Developmental origin of health and adult diseases (DOHaD): evolution of a concept over three decades. Med. Sci. M/ S 32, 15-20. http://dx.doi.org/10.1051/medsci/20163201004.

Clapp, C., De La Escalera, G.M., 2006. Aquaporin-1: a novel promoter of tumor angiogenesis. Trends Endocrinol. Metab. 32. http://dx.doi.org/10.1016/j. tem.2005.11.009.

Cunha, G.R., Donjacour, A.A., Cooke, P.S., Mee, S., Bigsby, R.M., Higgins, S.J. Sugimura, Y., 1987. The endocrinology and developmental biology of the prostate. Endocr. Rev. 8, 338-362. http://dx.doi.org/10.1210/edrv-8-3-338.

Dearden, L., Ozanne, S.E., 2014. The road between early growth and obesity: new twists and turns. Am. J. Clin. Nutr. 100, 6-7. http://dx.doi.org/10.3945/ ajcn.114.090449.

Ferrara, N., Gerber, H.P., LeCouter, J., 2003. The biology of VEGF and its receptors. Nat. Med. 9, 669-676. http://dx.doi.org/10.1038/nm0603-669.

Fischbeck, K.L., Rasmussen, K.M., 1987. Effect of repeated reproductive cycles on maternal nutritional status, lactational performance and litter growth in ad libitum-fed and chronically food-restricted rats. J. Nutr. 117, 1967-1975.

Gao, H., Sathishkumar, K.R., Yallampalli, U., Balakrishnan, M., Li, X., Wu, G., Yallampalli, C., 2012. Maternal protein restriction regulates IGF2 system in placental labyrinth. Front. Biosci. (Elite Ed) 4, 1434-1450.

Gosby, A.K., Stanton, L.M.L., Maloney, C.A., Thompson, M., Briody, J., Baxter, R.C., Bryson, J.M., Denyer, G.S., Caterson, I.D., 2009. Postnatal nutrition alters body composition in adult offspring exposed to maternal protein restriction. Br. J. Nutr. 101, 1878-1884. http://dx.doi.org/10.1017/S0007114508135851.

Guzmán, C., Cabrera, R., Cárdenas, M., Larrea, F., Nathanielsz, P.W., Zambrano, E., 2006. Protein restriction during fetal and neonatal development in the rat alters reproductive function and accelerates reproductive ageing in female progeny. J. Physiol. 572, 97-108. http://dx.doi.org/10.1113/jphysiol. 2005.103903.

Guzmán, C., García-Becerra, R., Aguilar-Medina, M.A., Méndez, I., Merchant-Larios, H., Zambrano, E., 2014. Maternal protein restriction during pregnancy and/or lactation negatively affects follicular ovarian development and steroidogenesis in the prepubertal rat offspring. Arch. Med. Res. 45, 294-300. http://dx.doi.org/ 10.1016/j.arcmed.2014.05.005.

Hivert, M.F., Perng, W., Watkins, S.M., Newgard, C.S., Kenny, L.C., Kristal, B.S., Patti, M.E., Isganaitis, E., DeMeo, D.L., Oken, E., Gillman, M.W., 2015. Metabolomics in the developmental origins of obesity and its cardiometabolic consequences. J. Dev. Origins Health Dis. 6, 1-14. http://dx.doi.org/10.1017/ S204017441500001X.

Khorram, O., Khorram, N., Momeni, M., Han, G., Halem, J., Desai, M., Ross, M.G., 2007 Maternal undernutrition inhibits angiogenesis in the offspring: a potential mechanism of programmed hypertension. Am. J. Physiol. Regul. Integr. Comp. Physiol. 293, R745-R753. http://dx.doi.org/10.1152/ajpregu.00131.2007.

Kim, J., Jung, Y., 2011. Different expressions of AQP1, AQP4, eNOS, and VEGF proteins in ischemic versus non-ischemic cerebropathy in rats: potential roles of AQP1 and eNOS in hydrocephalic and vasogenic edema formation. Anat. Cell Biol. 44, 295-303.

Langley-Evans, S.C., Sculley, D.V., 2006. The association between birthweight and longevity in the rat is complex and modulated by maternal protein intake during fetal life. FEBS Lett. 580, 4150-4153. http://dx.doi.org/10.1016/j. febslet.2006.06.062.

Liu, X., Lin, Y., Tian, B., Miao, J., Xi, C., Liu, C., 2014. Maternal protein restriction alters VEGF signaling and decreases pulmonary alveolar in fetal rats. Int. J. Clin. Exp. Pathol. 7, 3101-3111.

Ozanne, S.E., 2001. Metabolic programming in animals. Br. Med. Bull. http://dx.doi. org/10.1093/bmb/60.1.143.

Ozanne, S.E., Hales, C.N., Hales, P.C.N., 1999. The long-term consequences of intrauterine protein malnutrition for glucose metabolism. Proc. Nutr. Soc. 58, 615619. doi: S0029665199000804 [pii]. 
Pinho, C.F., Ribeiro, M.A., Rinaldi, J.C., Felisbino, S.L., Pinheiro, P.F., Domeniconi, R.F. Fochi, R.A., Boer, P.A., Scarano, W.R., 2014. Gestational protein restriction delays prostate morphogenesis in male rats. Reprod. Fertil. Dev. 26, 967-973. http:// dx.doi.org/10.1071/RD13132.

Prins, G.S., Putz, O., 2008. Molecular signaling pathways that regulate prostate gland development. Differentiation 76, 641-659. http://dx.doi.org/10.1111/j.14320436.2008.00277.x.

Prins, G.S., Birch, L., Greene, G.L., 1991. Androgen receptor localization in differen cell types of the adult rat prostate. Endocrinology 129, 3187-3199. http://dx. doi.org/10.1210/endo-129-6-3187.

Ramos, C., da, F., Babinski, M.A., Costa, W.S., Sampaio, F.J.B., 2010. The prostate of weaned pups is altered by maternal malnutrition during lactation in rats. Asian J. Androl. 12, 180-185. http://dx.doi.org/10.1038/aja.2009.69.

Reeves, P.G., Nielsen, F.H., Fahey, G.C., 1993. AIN-93 purified diets for laboratory rodents: final report of the American institute of nutrition ad hoc writing committee on the reformulation of the AIN-76A rodent diet. J. Nutr. 123, 19391951. http://dx.doi.org/10.1017/CBO9781107415324.004.

Rinaldi, J.C., Justulin, L.A., Lacorte, L.M., Sarobo, C., Boer, P.A., Scarano, W.R., Felisbino, S.L., 2013. Implications of intrauterine protein malnutrition on prostate growth, maturation and aging. Life Sci. 92, 763-774. http://dx.doi. org/10.1016/j.lfs.2013.02.007.

Rodríguez-González, G.L., Reyes-Castro, L.A., Vega, C.C., Boeck, L., Ibáñez, C. Nathanielsz, P.W., Larrea, F., Zambrano, E., 2014. Accelerated aging of reproductive capacity in male rat offspring of protein-restricted mothers is associated with increased testicular and sperm oxidative stress. Age (Dordr) 36, 9721. http://dx.doi.org/10.1007/s11357-014-9721-5.

Rossiter, H., Barresi, C., Ghannadan, M., Gruber, F., Mildner, M., Födinger, D. Tschachler, E., 2007. Inactivation of VEGF in mammary gland epithelium severely compromises mammary gland development and function. FASEB J. 21 3994-4004. http://dx.doi.org/10.1096/fj.07-8720com.

Saadoun, S., Papadopoulos, M.C., Hara-Chikuma, M., Verkman, a.S., 2005 Impairment of angiogenesis and cell migration by targeted aquaporin-1 gene disruption. Nature 434, 786-792. http://dx.doi.org/10.1038/nature03460.

Sene, L.D.B., Mesquita, F.F., de Moraes, L.N., Santos, D.C., Carvalho, R., Gontijo, J.A.R., Boer, P.A., 2013. Involvement of renal corpuscle microRNA expression on epithelial-to-mesenchymal transition in maternal low protein diet in adult programmed rats. PLoS One 8, e71310. http://dx.doi.org/10.1371/journal. pone.0071310.
Sha, X., Xiong, Z., Liu, H., Di, X., Ma, T., 2011. Maternal-fetal fluid balance and aquaporins: from molecule to physiology. Acta Pharmacol. Sin. 32, 716-720. http://dx.doi.org/10.1038/aps.2011.59.

Smith, L.E., Shen, W., Perruzzi, C., Soker, S., Kinose, F., Xu, X., Robinson, G., Driver, S., Bischoff, J., Zhang, B., Schaeffer, J.M., Senger, D.R., 1999. Regulation of vascular endothelial growth factor-dependent retinal neovascularization by insulin-like growth factor-1 receptor. Nat Med. 5, 1390-1395.

Snoeck, A., Remacle, C., Reusens, B., Hoet, J.J., 1990. Effect of a low protein diet during pregnancy on the fetal rat endocrine pancreas. Biol. Neonate 57, 107118.

Tammela, T., Enholm, B., Alitalo, K., Paavonen, K., 2005. The Biology of Vascular Endothelial Growth Factors. Cardiovasc. Res. http://dx.doi.org/10.1016/ j.cardiores.2004.12.002.

Tarry-Adkins, J.L., Ozanne, S.E., 2014. The impact of early nutrition on the ageing trajectory. Proc. Nutr. Soc. 73, 289-301. http://dx.doi.org/10.1017/ S002966511300387X

Thornburg, K.L., 2015. The programming of cardiovascular disease. J. Dev. Origins Health Dis. 6, 366-376. http://dx.doi.org/10.1017/S2040174415001300.

Timms, B.G., Mohs, T.J., Didio, L.J., 1994. Ductal budding and branching patterns in the developing prostate. J. Urol. 151, 1427-1432.

Vega, C.C., Reyes-Castro, L.A., Rodríguez-González, G.L., Bautista, C.J., VázquezMartínez, M., Larrea, F., Chamorro-Cevallos, G.A., Nathanielsz, P.W., Zambrano, E., 2016. Resveratrol partially prevents oxidative stress and metabolic dysfunction in pregnant rats fed a low protein diet and their offspring. J. Physiol. 594, 1483-1499. http://dx.doi.org/10.1113/JP271543.

Verkman, A.S., 2002. Aquaporin water channels and endothelial cell function. J. Anat. http://dx.doi.org/10.1046/j.1469-7580.2002.00058.x.

Viana, I.M.M.N., de Almeida, M.E.S., Lins, M.P., dos Santos Reis, M.D., de Araújo Vieira, L.F., Smaniotto, S., 2015. Combined effect of insulin-like growth factor-1 and CC chemokine ligand 2 on angiogenic events in endothelial cells. PLoS One 10, e0121249. http://dx.doi.org/10.1371/journal.pone.0121249.

Weibel, E.R., Kistler, G.S., Scherle, W.F., 1966. Practical stereological methods for morphometric cytology. J. Cell Biol. 30, 23-38. http://dx.doi.org/10.1083/ jcb.30.1.23.

Wong, L., Gipp, J., Carr, J., Loftus, C.J., Benck, M., Lee, S., Mehta, V., Vezina, C.M., Bushman, W., 2014. Prostate angiogenesis in development and inflammation. Prostate 74, 346-358. http://dx.doi.org/10.1002/pros.22751. 